\title{
Minding the pandemic
}

\section{A CSR perspective on patterns in Muslim religious responses to COVID-19}

DOI: https://doi.org/10.30664/ar.107742

(c) Attribution 4.0 International (CC BY 4.0)

\section{T} his article analyses clusters of Muslim responses to the COVID-19 pandemic in a theoretical framework provided by the cognitive science of religion. The responses include theological reflections on the origin, nature, and religious significance of the disease, religious justifications for restrictions on communal worship, apologetics in the light of COVID-19, and how aspects of the COVID-19 pandemic relate to issues of purity, impurity, and contagion. This article places the responses in a wider theoretical context that contributes to explaining their emergence as cultural representations, and, as a consequence, may promote further comparative research into responses to the COVID-19 pandemic in other religious traditions.

\section{Introduction}

The current article addresses Muslim religious responses to the COVID-19 pandemic. That is, it highlights cases where Muslims, confronted by the pandemic, have engaged publicly with established Islamic beliefs, practices, and forms of social organization belonging to what the anthropologist Dale Eickelman and political scientist James Piscatori have referred to as an Islamic 'pool of resources' (Eickelman and Piscatori 2004: 29). However, the article is not to be construed as an attempt at mapping such responses, with the aim of providing a general overview and system- atization. Such would be a formidable, and premature, task. ${ }^{1}$ When the first version of this article was drafted, there existed a limited number of academic studies providing information on such responses. The number has increased since then and will most probably continue to do so. Such studies are, given the global nature of the pandemic, by necessity all limited in scope. They focus on particular geographical regions or particular institutions, groups. or individuals, analysing the responses in light of the particular contexts - social, political, or cultural - in which they emerge and draw conclusions on diverse actors' possible motives and strategies. ${ }^{2}$

Such studies have provided valuable input for the current article, not least

1 For a recent attempt (in Danish) at such an overview, however, see Fibiger and Riexinger 2021.

2 For a recent example of a special issuepublication that covers Muslim responses to the pandemic in different geographical settings, which could be expected to be followed by others similar to it in the future, see the open access publication Tidskrift for Islamforskning 15(2) with the issue title Mediated Religious and Political Perspectives on COVID-19: Minority and Majority Views. 
regarding which responses have been selected for further discussion. This selection, however, has mainly been guided by an overall aim of exploring novel ways to interpret and understand the emergence of certain responses to the pandemic, using a theoretical framework of the cognitive science of religion, henceforth CSR. In short, as widely understood, CSR analyses phenomena relating to religious beliefs, practices, and forms of social organization in a framework of theories on how the human mind in general, and in everyday life, processes information, consciously and unconsciously, considering the role of such mental processes as perception, attention, memory, and emotions (Boyer 2001; Barrett 2004; Slone 2004; Whitehouse 2004; Lawson and McCauley 1990). Despite having become established - in the last three decades - as an important theoretical framework in the larger field of the study of religions, its impact in the subfield of Islamic studies has so far been marginal. In a recent article in Method and Theory in the Study of Religion, the Islamic studies scholar Aria Nakissa notes that 'generally speaking, specialists in Islam have hitherto taken virtually no interest in CSR' (Nakissa 2020a: 206). He himself is an exception (see also Nakissa 2020b); so is the present author. In a monograph (Svensson 2015) and a series of articles (e.g. Svensson 2017, 2020, 2021), I have explored the potential of different strands within CSR to provide explanatory frameworks for diverse elements in the Islamic tradition, historical and contemporary. The current article should be seen as part of this larger effort.

In what follows, I have thus selected a set of clusters of responses to the COVID19 crisis where, in my view, well-established research into how the human mind works has a potential to place these responses in an analytical framework that extends beyond the issue at hand, as well as beyond the particular Islamic context. The choice of clusters was made after consulting two forms of secondary sources: existing scholarly work on Muslim responses to the pandemic, and the almost daily update on media coverage of religious issues provided by the PEW International Research Center's newsletter Daily Religion Headlines. In the latter, 215 newsletters between January 2020 and January 2021 were scanned for news articles on Muslim religious responses to the pandemic.

From a longer initial list of candidate clusters of responses based on information in these secondary sources, I thus selected four that I deemed suitable for the overall aim as they could be further interpreted in light of themes within CSR which are both well established and clearly distinct from one another. The four clusters of responses selected concern theodicies of the pandemic, justifications for restrictions on religious worship resulting from the pandemic, religious apologetics, and, lastly, notions of purity, impurity, and contagion in the face of the pandemic. As a last step, some illustrative examples were collected by following up on references to primary sources found in both the academic publications and in the news articles. As is the case with the most currently available scholarly analyses of Muslim responses to the pandemic, the material is from online sources.

\section{Interpreting the virus: divine intentions and divine agency}

The first cluster of responses consists of attempts to make sense of the pandemic in light of notions of divine agency, and the intentionality behind such agency.

A belief in the omnipotence of the godhead is part of the Islamic pool of resources, 
expressed traditionally in the dogma of qada, and theologically elaborated as part of true faith (iman). Everything that transpires in this world does so because God so wills. There are several responses to COVID-19 that give God a causal role in the emergence and spread of the virus. One form of response identifies the disease as a divine punishment. In an analysis and categorization of content connected to the coronavirus and COVID-19 published between 20 January to 11 April 2020 on web fora associated with the movement known as the Islamic State, Chelsea Damon and Mieli Criezis found that 16 per cent of the postings presented the virus as divine punishment (Daymon and Criezis 2020: 29). The United Nations Interregional Crime and Justice Research Institute provides more reports on Islamic extremist groups favouring the narrative of divine punishment and cites statements of this kind as 'disinformation', citing examples from the Middle East, Central Asia, and Africa (UNICRI 2020: 3, 6, 15).

Looking more closely at these cases, it becomes clear that although they appear to share the notion that God is angry and uses the virus to punish humans, there are divergences concerning whom, exactly, God is angry with, and for what reasons. Candidates include China, because of the treatment of the Muslim Uighur minority in the Xinjiang province; a generic 'West', because of its oppression of Muslims globally, and Shiite Muslims because of their (from a Sunni perspective) heresies. In an analysis of the official Islamic State stance in the groups' newsletter al-Naba; Aymenn al-Tamimi, an often-consulted expert on the group, notes some change, over time, concerning the reasons for God's rage, depending on how the virus spread geographically and current hotspots (alTamimi 2020).
Perhaps mirroring a realization of the global nature of the pandemic, an official statement by another Islamic militant group, al-Qa ida, published on 31 March, identifies God as being angry with humanity at large, and not only with religious deviants, Chinese oppressors, or Western enemies. The pandemic is truly a punishment, and the divine message contained in it is for all humans to mend their ways and follow the straight path of Islam; this is the path the group advocates (MEMRI 2020). ${ }^{3}$

Evident in these responses is a distinction between different notions of punishment, as direct retribution in response to an evil act, and as a reminder or warning. The issue of different forms of punishment, in light of COVID-19, is elaborated upon in an article published by the modernist Islamic think-tank, The Yaqeen Institute, in April 2020. Here, the three authors claim that in Islam there is a differentiation between two forms of punishment: 'retributive punishment' against evil acts, and a 'nearer punishment' that serves as a test, or a corrective. The reference is to the Qur'an, verse 32:21. God indeed sends hardships, suffering, and death, but these serve a greater end: to make people mend their ways, seek forgiveness, and repent their sins, and also to display compassion and care for others. The authors here speak of a 'compassionate punishment' or punishment as a 'compassionate reprimand' (Umar et al. 2020). ${ }^{4}$

3 The English translation of this official statement can be found at Joscelyn 2020.

4 For a similar perspective voiced in the context of COVID-19, see Ahmad and Ahad 2021: 35-6. See also Sorgenfrei 2021 for an example from Sweden and Galal 2021: 127 for this as a shared view on the pandemic among state loyalist preachers in Egypt. For a more general outline of Muslim religious notions of divine agency, disease, and suffering, see Damian et al. 2016. 
Although not explicitly touching on the matter in terms of punishment, a similar notion of the pandemic as a divine test is voiced by the Islamic studies scholar Nazila Isgandarova in a co-written article on 'Buddhist, Muslim and Christian perspectives' on the pandemic (Xiong et al. 2020). Isgandarova claims (without any reference to empirical evidence, however) that the majority of observant Muslims view the COVID-19 as a test of humanity for their silence and lack of action before the suffering of innocent people and abuse of the nature' (p. 18).

In the examples cited, the common denominator is that of God as an active agent in the pandemic and as having intentions for his actions. This does not come as a surprise, and not only because of a cultural belief in divine omnipotence. Indeed, there are other responses that do not cite divine agency.

When Iran was heavily hit by the pandemic in March 2020, the supreme leader Ayatullah Ali Khamanei officially stated that the coronavirus may be a man-made biological weapon, created by the archenemy - the USA - and specifically targeting Iran (Gambrell 2020). In a similar mode, the militant Islamist group al-Shabab, in Somalia, claimed that the virus was part of biological warfare instigated by the 'crusader forces' (Harper 2020). 5 These responses, albeit produced by a high Iranian clergyman and a movement whose identity is firmly rooted in religion, do not cite an omnipotent divine agent. They are rather in line with the more general phenomenon of conspiracythinking on the emergence and spread of

5 See here also Galal 2021: 134-5 for notes on the Moroccan preacher Abdullah Nabari's conspirational views, that similarly exclude God as an active agent in the pandemic. diseases as the result of the vicious plans of other humans (Andrade 2020: 506-7). This illustrates how the Islamic pool of resources is not the only one available. It also illustrates how believers may on the one hand subscribe to a general, 'theologically correct', view but on the other hand deviate from this in their everyday thinking (Barrett 1990). 6

It has already been pointed out that even in cases of responses to the pandemic that do not cite divine agency, agency is still cited. This is in line with a more general human tendency to search for reasons for rather than causes of significant events, that is, to search for the underlying intentions of an agent (Lawson and McCauley 1990: 20-1). This tendency has been the object of particular attention in CSR, particularly in the discussion of a hyperactive agency detection device' (HADD) as a mechanism of the human mind (Guthrie 1993; Barrett 2004), a feature that within some strands of research has been identified as a major factor behind the emergence of religion. While there have been some challenges to the assumption of a specialized mental module for agency detection in recent years, ${ }^{7}$ the basic notion of humans being particularly liable to attribute agency and intentions in interpreting events is rarely questioned.

6 See Slone 2005 for a general discussion on notions of divine omnipotence and predestination as basically off-line theological reflections that conflict with on-line religious thinking, the latter being conditioned by everyday human information processing.

7 See here the special 2019 issue of the journal Religion, Brain and Behavior 9(1), with the target article by Marc Andersen, advocating 'predictive coding' instead of HADD to account for agency detection (Andersen 2019). 
The way in which humans attribute underlying driving forces of a religious nature (i.e. as the intentional actions of superhuman agents) to events has been shown to be dependent on the character of the event. Not all events are equally likely to be conceived in this manner. Research in the context of attribution theory has noted that individuals that believe in superhuman agents tend to involve these agents as parts of an explanatory chain behind events when the events in question affect them personally and have positive outcomes. Research has also noted, however, that there is an exception to this general tendency: medical and health-related events. These tend more often to be attributed to divine agency, despite their negative character, and regardless of whether they affect the individual making the attribution (Spilka and Schmidt 1983).

Attribution of COVID-19 to divine agency, however, is only the first step. A second step is constructing the intentionality behind the act. It is likely that once an event has been attributed to divine agency, the search for reasons for the actions begins, which then activates the human faculty of 'mentalizing', sometimes referred to as a 'theory of mind' (Sodian and Kristen 2010; Premack and Woodruff 1978; Baron-Cohen 1995), that is the creation of a mental representation of someone else's 'inner world' of beliefs, motives, wishes, emotions etc. In the responses above, it would appear that the construal of such intentions is flexible and conditioned by how events transpire. It is also perhaps dependent on a general world view. The notion of COVID-19 as a retributive punishment would appear to prosper in ideological contexts of confrontation, for example among militants. ${ }^{8}$ The

8 See e.g. Nichols 2014: 972, 85-9 for a discussion on divine punishment in context of notion that God punishes the evil-doing enemy, in this life or in the next, is also in line with what has been suggested as a general human tendency to construct 'justworld theories', that is to say views that 'the world is a just place in which individuals get what they deserve' (Hafer and Begue 2005: 128). This tendency appears to be quite independent of the presence of religious beliefs, and notions of a superhuman agent as the administer of justice. It may be conceived in a general, non-religious manner: 'what comes around goes around' (Baumard and Boyer 2013; Baumard and Chevallier 2012).

In the case of the 'nearer punishment', and notions of divine didactic intentions with COVID-19, however, there would appear to be less connection to a tendency for 'just-world theories', and God's actions fit rather into a model of the end justifying the means. Death as a result of COVID-19, however, is a different matter. The death of 'innocents', who do not reap the benefits of compassionate punishment, could be expected to go against an intuitive notion of a 'just world'. It is perhaps in this light that one should view another selection from the pool of resources: martyrdom.

There are Muslim responses to the COVID-19 pandemic that identify those dying from the disease as martyrs (see e.g. Khan and Zaman 2020; AMJA Resident Fatwa Committee 2020; Islamic Affairs \& Charitable Activities Department 2020; Gori 2021: 73-4). A martyr, shahid, has a special status in the Islamic tradition, entering into paradise immediately after death, to be richly rewarded. The Islamic tradition contains theological elaborations on who qualifies as a martyr, as well as different categories of martyrs. The prototypical martyr

religious in-group and out-group distinctions and conflicts. 
is the person who dies in armed combat in a just war. However, there are other categories as well: martyrs of a second degree. These include, among others, women who die during childbirth, people who die by drowning, those who die because a wall falls onto them, those who are killed by wild animals (Cook 2007; Kohlberg 2012). Most importantly for the issue of the pandemic, however, are people who die of certain diseases.

Assuming that humans tend to interpret events in a manner that conforms to notions of a 'just world', the cultural creation of specific categories of martyrs makes sense. The categories include victims of 'natural evils', that is to say events that are not the results of human intentional action (but perhaps ultimately God's intentional action). The compensation in the form of the elevation to the status of martyrs satisfies the demand for justice. Death by COVID19 is not a punishment, but a blessing. Recent experimental research has indicated a 'God-serving bias' in attribution among Christians with strong beliefs in an active, intervening superhuman agent. They are less inclined to attribute events with negative outcomes to that agent, as compared to events with positive outcomes (Riggio et al. 2018). Views on death by COVID-19 and martyrdom may testify to another means to achieve the same end: a reinterpretation of the outcome as not negative but positive.

\section{Justifying restrictions: inferentialism and deferentialism}

During the pandemic, the nations of the world have taken measures that directly affect religious practices. These include the closing down and re-opening of places of worship, such as mosques and shrines. States have furthermore instigated and enforced restrictions on public and private religious gatherings, communal com- memorations, rituals, festivities, and pilgrimages.

The arguably most noted restriction, at least as covered in the international media, was that imposed on the 2020 annual pilgrimage, hajj, to Mecca in late July to early August. Despite some initial speculations on its cancellation, and some countries banning participation for their citizens, the hajj was carried out. It was, however, organized in an atypical manner. The usual number of pilgrims, exceeding two million, was reduced to 10,000 - all residents of Saudi Arabia. The ritual events were either strictly controlled or, in the case of non-mandatory rituals, suspended. Among the latter were drinking from the well of Zamzam and kissing the black stone. Zamzam water was drunk, however, but distributed to the pilgrims in sealed plastic bottles (Zumla et al. 2020).

While unusually extensive, the restrictions and controls of the 2020 hajj had no need to be religiously controversial. Hajj is already highly restricted and orchestrated. Although the number of pilgrims each year exceeds two million, this is only a fraction of those from around the world who want to participate each year. Several tragic incidents over the years have also led Saudi Arabia to take measures to ensure that overcrowding is avoided. Touching or kissing the black stone may be a dream for many pilgrims, but an actual opportunity only for a few.

Other restrictions on worship, however, are more controversial. These become especially problematic for governments that are already the targets of religiously articulated criticism and opposition (see e.g. Ahmed 2020; Fahmi 2020). To counter religiously based criticism, the authorities - or rather the religious bodies loyal to such authorities - have attempted to justify controversial restrictions religiously. Such 
attempts at justification constitute another cluster of religious responses to COVID-19.

Here, I will limit myself to justifications of perhaps the most controversial of restrictions: the closing-down of mosques. Mosques are places of communal worship, and some Muslims will insist, on the basis of a general view of the particular merits of performing prayers together with others, on praying in these facilities. Communal gatherings in mosques occur also at other times, not least during Ramadan, when devout believers will perform supplementary prayers at night (tarawih) or practise $i$ 'tikaf, that is spending longer periods of time - days, weeks, or even the whole month - in the mosques. Mosque closures in 2020 severely restricted such practices. The most controversial restriction during 2020, however, concerned the suspension of mid-day Friday prayer, juma'a.

Unlike other activities in the mosque, attendance at juma'a prayer is, according to Islamic tradition, considered an individual religious obligation (fard) incumbent on any mature and healthy Muslim man (not woman). Not to participate is a sin. Hence, a ban on Friday communal prayer in the mosques is effectively a ban on Muslim men fulfilling their basic religious duties. This becomes particularly problematic when considering some elements in the pool of resources, relating to (Sunni) Islamic religio-political theory. Here, a commonplace view is that a ruler, even an oppressive one, should be obeyed in order to avoid chaos (fitna). There are limits, however. In order to claim obedience, the ruler must ensure that his subjects can perform their basic religious duties. Failure to do so is legitimate grounds for rebellion (Lewis 1988: 69). It is easy to see how a ban on Friday worship could be exploited in a religio-political agitation, and also to understand why this extraordinary measure requires extraordinary religious justification.

On 15 March 2020 the Supreme 'Ulama Council of Al-Azhar University in Egypt, arguably the most prestigious institution in Sunni Islam, issued a fatwa on the question of Friday prayer suspension. The fatwa deemed suspension to be religiously legitimate, given the need to control the pandemic. Particularly interesting in this case was that the person posing the question was Dr Arif Alvi, the president of Pakistan. On 25 March, Dr Alvi published a translation of the fatwa in Urdu on the Pakistani president's official Twitter account, thanking the Supreme 'Ulama Council, and also urging 'our Ulema to take action.' This statement must be seen in light of the fact that restrictions on public worship have been particularly controversial in Pakistan (Ahmed 2020; Riexinger 2021: 91-2).

How, then, may suspending Friday prayer in mosques be religiously justified? In order to exemplify, I turn to another fatwa, containing a lengthy elaboration that recurs in similar responses around the Muslim world, often responses produced by religious bodies loyal to the powers that be (see e.g. Begović 2020: 247-8; Fibiger and Riexinger 2020: 155-6). It was published on 3 March 2020 by the United Arab Emirates Council for Fatwa, a recently created body (2018) with ambitions of reaching a global audience (UAE Council for Fatwa 2020). Its board of members includes the well-known preacher Hamza Yusuf Hanson, popular not least among Muslims in the West (al-Astewani 2021: 7).

9 The President of Pakistan 2020. Islamic studies scholar Martin Riexinger notes that this attempt at influencing the local clergy via al-Azhar was unsuccessful (Riexinger 2021: 92). 
The key argument of the fatwa relies on 'legal maxims' (qawa'id sharia) in Islamic jurisprudential tradition. Two such are quoted: 'Aversion of harm takes priority over acquisition of benefit', and 'Risk of individual harm is endured in order to repel public harm. The reference to these maxims, in Islamic legal thought also known as qawa id fiqhiya (Heinrichs 2012), rests on a notion in the Islamic legal tradition that underlying specific rulings on ritual and social issues contained in the Qur'an and the hadith, there are divine intentions: maqasid al-shari' $a$ or 'the purposes of the law' (Gleave 2012; Mustafa 2014: 1). The reference to legal maxims, thus, is a plea for mentalization, of simulating the divine mind in search of underlying intentions and using this simulation to qualify, suspend, or expand more specific demands. Even though God has ordered men to perform communal Friday prayer in mosques, this demand can be overlooked considering what he (assumedly) really wants in the face of the pandemic.

In an article from 2004, the anthropologist Maurice Bloch distinguishes between two main modes in which human beings process and react to social information. One mode involves observing action (speech or behaviour) thereby simulating the mind of the agent in search of underlying meaning. The other mode plainly accepts the given information at face value, deferring to it and allowing it to directly influence one's actions and disregard any possible intentions of the sender. In everyday life, humans alternate between these (Bloch 2004). I have elsewhere discussed these two modes in terms of inferentialism and deferentialism and have argued that the distinction is mirrored in different approaches by Islamic scholars in their attempts to infer the divine will from the religious scriptures (Svensson 2015: 147-9).
In the fatwa, the reference to the 'legal maxims' aims to activate the inferentialist mode. However, the fatwa also contains arguments that are rather appeals to deferentialism. There are direct references to the scriptures, with an implicit demand that these should be taken at face value. God has decreed, in the Qur'an (with direct reference to verse 4:59), that believers should 'obey those in authority'. 'Numerous hadith' testify to the same command. Likewise, God has demanded in the Qur'an that believers should not 'destroy one another' (4:29) and commanded them 'do not contribute to your destruction with your own hands' (2:195). Deferentialism is also evident in the reference to a particular hadith on how Muhammad once banned a man from attending communal prayer because the Prophet found his odour disturbing. The intentions behind the Prophet's act are, in this case, irrelevant. The point is to show that the act of banning someone from communal prayer can be religiously justified.

One could pose the question why there is a mix in the fatwa between inferentialism and deferentialism. Would not the 'legal maxims' suffice? Perhaps, but one of the major problems with inferentialism is that it carries with it an element of uncertainty, given that it rests on simulation of the mind of the sender of information. There is no such uncertainty in deferentialism. Indeed, as Aasim Padela and his coauthors note (Padela et al. 2014: 3), there is some reservation in the Islamic legal tradition concerning the extensive use of 'legal maxims'. It may only be used in cases where there is no clear answer provided by a literalist reading of the scriptures, an answer that can be simply deferred to.

Some hadith quoted in the fatwa do not directly connect to the main topic (suspension of communal prayer). These include: 'If you hear of an epidemic afflicting a land, 
do not enter it, and if it afflicts the land you are in, do not leave it'; 'Do not introduce infectious livestock into a healthy herd' and 'Flee from leprosy as you flee from a lion'. All relate to measures taken by authorities worldwide to combat the pandemic - quarantine and social distancing. Such measures are not controversial from a religious point of view. The references may be intended to motivate Muslims to adhere to such measures. However, the fact that they recur prominently in Muslim discourses on the pandemic, as well as in contexts other than ones providing guidelines for actions, prompts a search for another explanation.

\section{Apologetic approaches}

The references to hadiths quoted above serve to show that in the Islamic tradition there are elements from more than a millennium ago that are in accordance with, and support, measures taken globally to combat the current pandemic, measures based on medical experience and science. ${ }^{10}$

Such connections are forged not only with explicit statements in the scriptures, but also with other elements in the pool of resources. One recurring connection is that between recommendations of hand washing with soap and basic hygiene to avoid infection, and Islamic practices of ritual purification (see e.g. Aslan 2020; Sofouglu 2020; Musa et al. 2020). Commentators point to a focus in Islam on 'cleanliness', at times citing the well-known hadith that 'cleanliness [tuhur] is half the faith. ${ }^{11}$ Again, the implicit claim is that Islam already, for over a millennium, has included practices

10 For additional examples, see Riexinger 2021: 101-5 (Pakistan and India) and Galal 2021: 128-30 (Arab countries).

11 Sahih Muslim, book 2, no. 1 (for Arabic original and English translation, see sunnah.com, hadith 23). that correspond to scientifically based preventative measures to curb the spread of COVID-19.

To be in a state of ritual purity (tahara) is a prerequisite for the performance of basic rituals. Such purity is attained through ritual cleansing: wudu' (minor) and ghusl (major). Water plays an important role in traditional prescriptions for these cleansing rituals. Soap (and definitely not alcohol; see below) does not. In fact, if no water is available, cleanliness can be attained in wudu by using, for example, sand, a stone wall, or a particular 'cleansing stone' (tayammum stone) (Chaumont 2012), neither of which features in any recommendations on hygiene in the context of the pandemic.

This response to the pandemic hence involves considering the contemporary situation and looking into the pool of resources for elements that can be interpreted as being (somewhat) in line with generally accepted truths concerning how to combat the pandemic. As the philosopher Dariusch Atighetchi has noted in his study of Islamic bioethics, this is a recurring feature in religiously-oriented discussions on health, medicine and medical ethics. He terms it an 'apologetic approach' (Atighetchi 2007: 200).

In a blog post published on 8 September 2020 the ethologist and atheist champion Richard Dawkins briefly discusses another, slightly different, 'apologetic approach' to COVID-19, published in the Indian online magazine The Muslim Mirror. The author of the article, a Dr Abdul Rashid Agwan, claims that the pandemic had been foretold in the Qur'an, particularly in the eschatologically-oriented chapter 74 . The references are to verse 8 , and the word naqur, containing the root consonants $q-r-n$, which then (almost) spells 'corona'. While generally interpreted as referring to the trumpet that will sound at the end of 
days, it can also, according to the author, have a semantic connection to 'horn', which then brings to mind the physical structure of the coronavirus, as a sphere with 'horns'. When ' 19 ' is mentioned in verse 30 of the same chapter ('and over it are nineteen') the case is closed (Agwan 2020). This is but one of several attempts to show how not only are certain recommended practices foretold in Islamic tradition, but even the pandemic itself (see e.g. Khenenou et al. 2020; Madjid 2021; Tamburini 2021).

Dawkins is not impressed. In a sarcastic comment he writes: 'Admiring as I already was of the Quran's prescience in foretelling the detailed facts of embryology (the embryo looks like a leech) nothing could have prepared me for the uncanny accuracy with which it foresaw Covid-19' (Dawkins 2020). The comment alludes to a tendency in contemporary Islamic thought that in some scholarly contexts has been termed the 'scientific exegesis' of the Qur'an (Wielandt 2001; Stenberg 1996). The basic claim is of modern scientific discoveries being mentioned in the sacred text. This is an apologetic tendency that stretches beyond the domains of medicine and science, where interpreters search the pool of resources for content that, with the right interpretation, can be connected to such modern phenomena as human rights, gender equality, and environmental care (see e.g. Zafrulla Khan 1988; Khalid 2019; Barlas 2004).

At times, such attempts could be construed as strategic. Certain contemporary ideals and concepts, such as human rights and gender equality, are often religiously controversial. 'Proof' that they are inherently Islamic comes in handy in contexts where religious legitimacy is important. In the case of the responses to the pandemic under study here, such strategic considerations are less obvious. There is a complementary interpretation. One of the more robust findings in the scientific search for patterns in human cognition is that of a confirmation bias. As human beings we have a tendency, in general, to process new information in a manner that corresponds to what we already think we know. A particular form of confirmation bias has been termed 'myside bias': a tendency to search for and interpret new information in a manner that lends credence to already-held beliefs (Keith et al. 2013; Mercier 2017; Hahn and Harris 2014: 46). Some recent research even indicates that this tendency may be stronger in cases where there is conscious and deliberate processing of information in relation to beliefs held, for example theological reflection (Dickinson 2020).

In the cases noted above, information on the coronavirus, COVID-19, and different preventative measures taken worldwide are related to a selective set of content from the pool of resources and serve to confirm the general belief in an active superhuman agent with extensive knowledge and foresight, and the veracity and value of the channels (the Qur'an and the Prophet) that he has utilized in history to communicate with human beings. In a sense, these cases show how theological thinking can 'cash in' on the pandemic. Such a strategy may take different forms. Finding detailed predictions of the pandemic in the Qur'an may not be that convincing to a general audience, and particularly not a non-Muslim one. Other forms of attaching content from the pool of resources to the current situation may be more acceptable, and welcome, even in academic publications (for an example, see Ahmad and Ahad 2021).

There is a flip side to confirmation bias. Information that challenges beliefs held is either ignored, or the information, or the beliefs, are reinterpreted or modified 
in order to reduce 'cognitive dissonance' (Festinger 1976). In the context of COVID19, there is one element in the pool of resources that is conspicuously absent in the responses to the pandemic. In an utterance ascribed to Muhammad, recorded in several versions in the hadith-literature, the Prophet is reported to have said 'there is no 'adwa'. The standard translation of 'adwa is 'transmission of disease'. A search on the database sunnah.com returned no less than 16 versions of this hadith from three different hadith collections. Historically, the hadith has been interpreted as a denial of the infectious nature of diseases. The statement 'no 'adwa', would appear to contradict some hadith content quoted in the fatwa above: 'Do not introduce infectious livestock into a healthy herd' and 'Flee from leprosy as you flee from a lion'. In fact, these statements appear in the 'no 'adwa' hadiths, ${ }^{12}$ producing an internal contradiction in the hadith that has not passed unnoticed in the Islamic tradition, especially in the sub-field of 'Prophetic medicine' attempting to fuse the Galenic tradition with content from the hadith collections and the Qur'an. Is leprosy an exception to the general rule that there are no contagious diseases? Did the Prophet accept the fact of contagious diseases among animals, but not humans? (See Stearns 2010, 2007; Dols 2012.)

In searching for Muslim responses to COVID-19 in 2020 I have only come across reference to the 'no 'adwa' hadiths in contexts that question that the Prophet would ever have denied the transmissible nature of diseases. ${ }^{13}$ Ovamir Anjum, who holds

12 Sahih al-Bukhari, book 76 , no 87 and Sahih al-Bukhari, book 76, no. 27 (for Arabic original and English translation, see sunnah.com, hadiths 5773-5 and 5707).

13 Riexinger (2021:107) also notes a conspicuous absence of notions the a chair in Islamic studies at the University of Toledo, has a similar experience, but has also himself produced a lengthy elaboration, in light of the COVID-19 pandemic (Anjum 2020). After noting the apparent contradictions, he reaches the conclusion that what the Prophet 'really' meant by the utterance 'no 'adwa' was not a denial of disease transmission, but a refutation of superstition that disease was caused by 'transferrable evil spirits', competing with God as superhuman causal forces in the world.

What the Prophet really meant, based on the hadith literature, is not a question to be answered by a scholar in Islamic studies. The dominant view among Islamic studies scholars has long been that this particular body of texts is of little value as a source of knowledge on the historical Muhammad. Anjum's text shows, however, that contemporary Muslim conceptions of what the Prophet 'really' meant by an alleged utterance may be conditioned by (1) the view that the Prophet could not be wrong and (2) what the interpreter, and most people in the world, know to be the actual truth of the matter.

\section{Contagion}

In a couple of longer 'no 'adwa' hadiths, the Prophet's statement is met by an objection, apparently based on experience, from the audience: 'Don't you see how camels on the sand look like deer but when a mangy camel mixes with them, they all get infected with mange?'14 Whether or not this is an authentic objection to an authentic Prophetic utterance is, as has already

non-transmittability of diseases in his analysis of responses to the pandemic in India and Pakistan.

14 Sahih al-Bukhari, book 76, no 87 (for Arabic original and English translation, see sunnah.com, hadiths 5773-5). 
been stated, impossible to ascertain. It implies, however, that at least at the time when the hadith was put into writing (the 9th century) a claim that disease was not transmissible could be questioned.

Thus, the conspicuous absence of reference to the Prophetic statement 'no ' $a d w a$ ' in responses to the COVID-19 pandemic may not only be attributable to the fact that if understood as a denial of the transmissible character of diseases, it contradicts contemporary scientific knowledge; it may also contradict more basic human understandings of contagion. Given modern knowledge of viruses and bacteria as 'agents' of disease transmission, it could be concluded that the view among the preIslamic Arabs, according to Anjum, was perhaps not that far off the mark.

Cultural notions that invisible 'stuff' may be transferred from an object to another object, and further on to other objects, upon physical contact, and that this transfer produces change in the receiving object, is by no means a novel phenomenon, and not dependent upon modern science. There has been much experimental research since the late 1980s, not least by the psychologists Paul Rozin and Carol Nemeroff (Rozin et al. 1989; Rozin and Nemeroff 1990; Nemeroff and Rozin 1994, 2018) that supports the hypothesis of a pan-human proclivity for thinking along such lines. Such research has mainly focused on behaviour, emotions, and conceptions related to 'contagion avoidance'. Humans avoid objects, persons, or places they perceive of as potential sources of contamination, either inherently so, or because these have been themselves contaminated through physical contact with such a source. Avoidance behaviour is often mediated by the emotion of disgust (for an overview of this research, see Kelly 2011).

A commonplace explanation for the emergence of a what may be termed a human 'contagion-avoidance system' is evolutionary (Curtis 2007; Curtis et al. 2011). It has evolved because it has served as a protection against infection. This is supported by the fact that a rudimentary form of such a system is found in other species, as a 'behavioral immune system' (Schaller and Park 2011). As far as we know, humans are the only species to have developed notions of a causal chain involving the transfer of some 'stuff' between a source and target, and further on in a chain of contamination, probably because we have a particular ability to form mental representations of what is not directly detectable by the senses. This ability to represent invisible contagious 'stuff' has been adaptive, because such stuff exists: bacteria, viruses and parasites.

It is true that cross-cultural research into disgust has shown that some objects, substances, and visible signs of infection in other humans tend to elicit emotions of disgust and motivate avoidance behaviour in different cultural contexts around the world (Curtis et al. 2011). It is, however, also true that what humans find disgusting and avoid contact with varies across time and space, and is highly susceptible to change through social information. This makes the human behavioural immune system more flexible than in other species. But it also makes it susceptible to cultural exploitation. In a variety of religious traditions, including Islam, there are extensive systems of notions of pure and impure substances, objects, places, and persons with which contact should be avoided (Katz 2002; Wensinck 2012). One case where issues of purity and impurity in the Islamic tradition have emerged in Muslim responses to the COVID-19 pandemic has already been mentioned: when practices to attain ritual purity are connected with recommendations on hygiene. Here I will, as a 
concluding section, point to an additional two instances: hand sanitizers containing alcohol, and vaccines against COVID-19.

In an official statement for 'Safe Ramadan Practices' the World Health Organization in April 2020 recommended that mosques 'provide alcohol-based hand-rub (at least $70 \%$ alcohol) at the entrance to and inside mosques' (WHO 2020: 2). The potential problem here, of course, is the well-known notion that consumption of alcohol is haram, forbidden, for Muslims, based on an interpretation of a step-wise banning in the Quran of khamr, commonly translated as 'wine' (Karic 2001). The legal schools (madhahib) agree that khamr is haram, but within the Hanafi school of law a more literal understanding of the text has also led to the conclusion that not all forms of alcohol are haram, since they do not belong to the khamr type. Most important here is that within the Hanafi school of law one finds the view that distilled alcohol is not khamr, and hence not forbidden (even to drink) (Wensinck and Sadan 2012; Michalak and Trocki 2006).

In the current discourse on the status of alcohol-based hand sanitizers and the pandemic the majority of religious scholars appear to view it as allowed. Arguments differ. Some point out that since the substance is not drunk, but used externally, the question of whether it is haram or not is irrelevant. Others claim, with reference to Hanafi tradition, that the alcohol used is not of a khamr type, and not made from khamr. Hence it is not forbidden (for examples, see Mufti of Federal Territory 2020).

Still, the issue does appear to produce some uncertainty among ordinary believers, an uncertainty related to the distinction between purity and impurity. One of the reasons may be a dual aspect of khamr/alcohol in Islamic legal tradition. Consuming it (as well as for example trading in or serving alcohol) is haram. In addition, khamr is also generally considered to be an 'unclean', najis, substance that like, for example, urine, blood, and faeces, renders a person ritually unclean upon contact. Opinions differ, however, concerning other types of alcohol (if they are differentiated from khamr) (Wensinck 2012).

The discussion is complex, but not new. It has previously concerned perfume, or medicines containing alcohol. It is no wonder that the complexity of the discourse creates uncertainty. This is an uncertainty that can also be exploited for financial gain. Some distributors of hand sanitizers have, allegedly, been labelling these products halal, even if they contain ethanol (Lim 2020; Rahmani 2020). The advice given by the international aid agency Islamic Relief in their recommendations for Covid-safe religious practice during the pandemic is also directed at those in doubt. According to that organization, even if you believe that external contact with alcohol breaks a state of ritual purity, this purity is easily regained through performing wudu' (Islamic Relief 2020: 5).

Things become a little more complicated with vaccines. These are not externally applied (or easily removed through $\left.w u d u^{\prime}\right)$, but injected into the body. Hence, at the time when the first vaccines were introduced one of the major religious questions was: are these vaccines halal?

Of particular concern appears to be whether vaccines contain traces of animal products, particularly of the porcine kind. Dietary rules in the Islamic tradition generally state that in order for meat to be considered halal for consumption, it has to be ritually slaughtered by a Muslim. There are exceptions, but these will not be addressed here. More important, however, is the ban on the consumption of meat from certain animals, including pigs (Francesca 2012). 
Pigs are also animals that in themselves, according to dominant tradition, are najis, as is every part of their bodies. The exception here is the Maliki madhhab, where live pigs are not considered impure (Wensinck 2012). Despite the fact that the major vaccines, according to the manufacturers, do not contain any porcine or animal substances, suspicions linger. The British Islamic Medical Association has produced an official statement on the matter concerning the Astra Zeneca vaccine (British Islamic Medical Association 2021).

In an article on precisely the issue of porcine substances in medicine, published in the journal Bioethics in 2013, the authors provide an excellent overview of the problem, which is by no means novel, or even modern, but has been discussed already by scholars of old. Indeed, the very root of the problem, from a theological point of view, lies in hadiths that explicitly ban using haram substances in medicine (Padela et al. 2014: 4). However, tradition has worked out exceptions. One way is to invoke the principle of darura, or 'necessity', in Islamic law: which can make acts lawful which are usually prohibited (Mustafa 2014: 2). Fittingly, the archetypical reference is to pork. Pork may be consumed if otherwise one risks starving to death. Protection of one's life overrules the prohibition. However, as Padela and his co-authors point out, there are certain reservations against invoking darura in medical treatment. A commonplace view is that darura applies only in life-threatening situations, and when the negative outcome, when the action is not undertaken, is certain. This does not always apply in medical treatment (Padela et al. 2014: 5) and may be particularly relevant in the case of COVID-19, where the aim of vaccination is not primarily a matter of saving the life of each individual vaccinated, but to stop the spread of the virus in society.
The second argument that Padela and his co-authors cite is that of istihala or transformation. Even if forbidden or unclean substances have been used, these substances have undergone some form of transformation and become purified. Scholarly discourse on such transformation has used as prototypical cases khamr turned into vinegar, and unclean raw animal skin which has become clean through the process of tanning. Concerning forbidden or unclean substances in medicine, there has, however, for a long time been a difference in opinion among different schools of law, where some have accepted istihala, while others have not (Padela et al. 2014: 5).

Vaccination programmes against COVID-19 are at the time of writing (April 2021) ongoing, and we are yet to see how Muslims around the world will respond, and what role religious considerations will play in their willingness or unwillingness to receive vaccination. However, it may be noted that although no vaccine on the market appears to use porcine substances in the production process, Islamic scholars in favour of vaccination have issued what could perhaps be construed as pre-emptive opinions on the matter. Hence, the abovementioned UAE Fatwa Council mentioned above has issued a fatwa justifying any vaccine, even if it contains porcine elements, on the basis of darura reasoning (Associated Press 2020). Al-Azhar's official organ for provision of fatwas, Dar ul-Ifta, chose the istihala alternative, claiming the vaccines to be halal because the production process changed any porcine components (Asharq Al-Awsat 2020). The Office of the Mufti in Singapore explicitly refers to both darura and istihala and cautions that 'The religious view of the COVID-19 vaccine must ... take a more holistic stance that transcends the issue of "halalness" or permissibility of its ingredients' (Office of the Mufti 2020). 
Arguments with reference to darura can be viewed as an inferentialist way of searching for divine guidance, where the perceived intent of the superhuman agent overrules his explicit commands, under certain circumstances. Such arguments rest on the human ability to mentalize. Arguments with reference to istihala have their foundation in another mental ability referred to in the context of the contagion system above: to form mental representations of 'stuff' undetectable by the senses and provide this 'stuff' with a role in a chain of causality. This ability, and proclivity, often referred to as 'psychological essentialism' is possibly unique to humans as a species and has been the object of psychological research since the late 1980 os (Medin and Ortony 1989; Gelman 2003; Haslam et al. 2013).

In the dominant Islamic traditions, pigs are inherently najis, and every part of their bodies contains, and can transmit, unclean 'pigness'. The pigness as such does not have to be detectable by the senses; it still contaminates upon contact. Among those who reject isthala the pigness remains in any medicine whose production has involved any part taken from a pig, however diluted or processed. For those who accept it, on the other hand, a process of human intervention and manipulation changes the pigness into 'non-pigness', just as ritual ablutions change a person from ritual impurity to ritual purity, also without any perceptual evidence that a change has occurred. It is important to note, however, that both positions share the basic conception that the mentally represented, invisible, pigness is real, and has real effects. What this pigness consists of is, as has been shown in research on psychological essentialism, of little relevance. The main function of essences is to serve as placeholders in a causal chain of reasoning (Gelman 2013: 450).

\section{Concluding remarks}

This article has addressed a limited set of four clusters of Muslim responses to COVID-19. Hence, it is by no means exhaustive. In the course of collecting information, I have come across other possible clusters that could also have been interpreted within the framework of CSR. Two such may be noted here, as suggestions for further inquiry. While only mentioned in passing above, the tradition of 'Islamic medicine' or 'Prophetic medicine' (Perho 1995), as well as other notions of 'Islamic' cures of COVID-19 and forms of protection against infection from the coronavirus (see, e.g. Sorgenfrei 2021: 56), is an area with some potential in this respect. Of particular interest would be notions that protection or cure may come from contact with, or proximity to, places, persons, substances, or objects containing a transmissible, sacred, and health-promoting 'essence.' 15 Such notions are well suited to further analysis within the frameworks of theories mentioned above concerning thinking on contagion and psychological essentialism. A second area for further study is cases where religious gatherings - for example festivals, pilgrimages, or mass funerals - become 'superspreader events' (Majra et al. 2021). Examples from a Muslim context are mass meetings of the transnational missionary group Tablighi Jama'at in India and in Singapore, and Shiite pilgrimages to the shrine of Fatemah-e Ma'sume in Qomm, Iran (Riexinger 2021: 94-7). Recent social psychological research, predating the pandemic, indicates that in social contexts where participants experience a shared social identity, an otherwise 'natural' social distancing in relation to strangers, medi-

15 For a reference to such notions in a Shiite context, see Galal 2021: 132. 
ated by emotions of disgust, is compromised (Hopkins and Reicher 2017; Hult Khazaie and Khan 2020). The role of shared religious beliefs and practices in strengthening notions of a shared identity within groups (see e.g. Atran and Hendrich 2010) may be a factor in explaining why religious gatherings feature among the more prominent superspreader events (Majra et al. 2021:38).

The object of study in this article has been recurring patterns in Muslim responses to the pandemic, patterns I claim can be interpreted within a CSR framework. This framework is not suited to the interpretation of singular, local responses in specific settings, and consequently is not to be viewed as a substitution for detailed contextual analysis heeding social, cultural, or political specificities of such responses. As noted in the introduction, research into such local or regional responses is ongoing. There has been a certain focus on more or less official, reflective responses of individuals, and groups that engage actively and purposefully with the religious tradition. Little attention has been paid to responses that emerge in everyday processes of making religious meaning. Collecting and analysing data concerning such processes is an important, but difficult task for future research. Perhaps the pandemic itself has led to a situation that is particularly beneficial for such research. In speculating on a possible post-pandemic situation, the Middle East studies scholar Georges Fahmi suggests, with reference to North Africa, that one possible outcome of the suspension of communal religious activities is the increased use of online resources even for activities that were previously exclusively conducted off-line (Fahmi 2020: 5-6). Some such channels used for outreach allow for user interaction in the form of comments or reactions. Cumulatively, the data generated by such user interaction, and its relative accessibility, may prove to be a virtual gold mine for future research into patterns in Muslim responses to COVID-19.

At the time of writing, the world is still under the yoke of the pandemic, and religious responses to it are continuously being produced. What general patterns will be discernible in the different ways that Muslims have responded religiously to the pandemic and how these patterns may be explained are questions that can only be answered through a joint effort by many researchers - researchers who will be able to return to the issue for quite some time to come.

\section{Jonas Svensson is}

a professor in the study of religions at Linnaeus University, Växjö, Sweden. The focus of his research is Islam, with a particular focus on contemporary interpret-

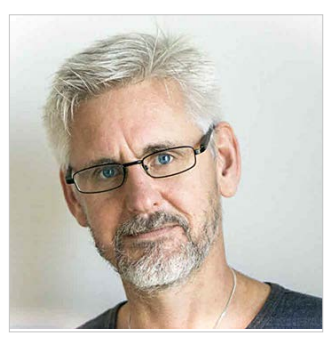
ations. He has published on issues such as Islam and gender, Islam and human rights, and Islamic religious education. In his more recent publications he has turned towards the cognitive science of religion (CSR), exploring its potential for bringing new theoretical input into the field of Islamic studies.

\section{References}

Agwan, Abdul Rashid. 2020. 'Probable mention of a COVID-19 like pandemic in the Quran', Muslim Mirror, 29.5.2020, <http://muslimmirror.com/eng/probable-mention-of-acovid-19-like-pandemic-in-the-quran/> (accessed 15.4.2021).

Ahmad, Zohaib, and Arzoo Ahad. 2021. 'COVID-19: a study of Islamic and scientific perspectives', Theology and Science 19(1): 32-41.

Ahmed, Imran. 2020. 'The politics of congregational prayer: trust, public health, and religious authority in Pakistan', Journal of Law, Religion and State 
8(2-3): 251-71, doi: <https://doi. org/10.1163/22124810-2020015>.

AMJA Resident Fatwa Committee. 2020. 'Are those who die from the coronavirus (COVID-19), martyrs?', Assembly of Muslim Jurists of America, 30.3.2020, <https:// www.amjaonline.org/fatwa/en/87743/ are-those-who-die-from-the-coronaviruscovid-19-martyrs $>$ (accessed 20.4.2021).

Andersen, Marc. 2019. 'Predictive coding in agency detection', Religion, Brain \& Behavior 9(1): 65-84, doi: <https://doi.org/10.108 o/2153599X.2017.1387170>.

Andrade, Gabriel. 2020. 'Medical conspiracy theories: cognitive science and implications for ethics', Medicine, Health Care and Philosophy 23: 1-14, doi: <https://doi. org/10.1007/s11019-020-09951-6>.

Anjum, Ovamir. 2020. 'Is contagion real? Giving context to prophetic wisdom', Yaqeen Institute for Islamic Research, 16.4.2020, $<$ https://yaqeeninstitute.org/ovamiranjum/ is-contagion-real-giving-context-to-prophetic-wisdom $>$ (accessed 16.4.2021).

Asharq Al-Awsat. 2020. 'Egypt's Dar al-Ifta authorizes use of COVID-19 vaccine containing pork components', Asharq Al-Awsat, 27.12.2020, <https://english.aawsat.com/ home/article/2706451/egypts-dar-al-iftaauthorizes-use-covid-19-vaccine-containing-pork-components> (accessed 19.4.2021).

Aslan, Rose S. 2020. 'What Islamic hygienic practices can teach when coronavirus is spreading, The Conversation, 16.3.2020, $<$ https://theconversation.com/whatislamic-hygienic-practices-can-teachwhen-coronavirus-is-spreading-133221> (accessed 20.4.2021).

Associated Press. 2020. 'The latest: UAE Islamic body OKs vaccines even with pork', Independent, 23.12.2020, <https:// www.independent.co.uk/news/the-latestuae-islamic-body-oks-vaccines-even-withpork-coronavirus-vaccines-muslims-peruvirus-vaccines-b1777996.html> (accessed 15.4.2021).

al-Astewani, Amin. 2021. 'To open or close? COVID-19, mosques and the role of religious authority within the British Muslim community: a socio-legal analysis', Religions 12(1): 11, doi: <https://doi.org/10.339o/ rel12010011>.
Atighetchi, Dariusch. 2007. Islamic Bioethics: Problems and Perspectives (Dordrecht: Springer).

Atran, Scott, and Joseph Henrich. 2010. 'The evolution of religion: how cognitive byproducts, adaptive learning heuristics, ritual displays, and group competition generate deep commitments to prosocial religions', Biological Theory 5(1): 18-30, doi: <https:// doi.org/10.1162/BIOT_a_00018>.

Barlas, Asma. 2004. Believing Women in Islam: Unreading Patriarchal Interpretations of the Qur'an (Karachi: SAMA).

Baron-Cohen, Simon. 1995. Mindblindness: As Essay on Autism and Theory of Mind (Cambridge: MIT Press).

Barrett, Justin L. 1990. 'Theological correctness: cognitive constraint and the study of religion, Method \& Theory in the Study of Religion 11(4): 325-39, doi: <https://doi. org/10.1163/157006899Xoo078>.

- - . 2004. Why Would Anyone Believe in God? (Walnut Creek: AltaMira Press).

Baumard, Nicolas, and Pascal Boyer. 2013. 'Explaining moral religions', Trends in $\mathrm{Cog}$ nitive Sciences 17(6): 272-80, doi: <https:// doi.org/10.1016/j.tics.2013.04.003 >.

Baumard, Nicolas, and Coralie Chevallier. 2012. 'What goes around comes around: the evolutionary roots of the belief in immanent justice, Journal of Cognition and Culture 12(1-2): 67-8o, doi: <http://dx.doi. org/10.1163/156853712X633938>.

Begović, Nedim. 2020. 'Restrictions on religions due to the COVID-19 pandemic: responses of religious communities in Bosnia and Herzegovina, Journal of Law, Religion and State 8(2-3): 228-50, doi: <https://doi. org/10.1163/22124810-2020007>.

Bloch, Maurice. 2004. 'Ritual and deference', in Ritual and Memory: Toward a Comparative Anthropology of Religion, eds. Harvey Whitehouse and James Laidlaw (Walnut Creek: AltaMira Press), 65-78.

Boyer, Pascal. 2001. Religion Explained: The Human Instincts that Fashion Gods, Spirits and Ancestors (London: Vintage).

British Islamic Medical Association. 2021. 'Position statement on the Oxford/AstraZeneca COVID-19 vaccine, British Islamic Medical Association, 10.1.2021, <https://britishima.org/covid19-vaccine-az/> (accessed 20.4.2021). 
Chaumont, E. 2012. 'Wudu', in Encyclopaedia of Islam, Second Edition, eds. P. Bearman, Th. Bianquis, C. E. Bosworth, E. van Donzel and W. P. Heinrichs (Leiden: Brill Online), doi: <http://dx.doi. org/10.1163/1573-3912_islam_SIM_7925>.

Cook, David. 2007. Martyrdom in Islam (Cambridge University Press).

Curtis, Valerie A. 2007. 'Dirt, disgust and disease: a natural history of hygiene', Journal of Epidemiology and Community Health 61(8): 66o-4, doi: <http://dx.doi.org/10.1136/ jech.2007.062380>.

- _ - and Mícheál de Barra, and Robert Aunger. 2011. 'Disgust as an adaptive system for disease avoidance behaviour', Philosophical Transactions of the Royal Society B: Biological Sciences 366(1563): 389-401, doi: <https://doi.org/10.1098/ rstb.2010.0117>.

Damian, Constantin Iulian, Nicolae Ghețu, Ioan Dura, and Vasile Astărăstoae. 2016. 'The Quranic instrumentalization of suffering', European Journal of Science and Theology 12(4): 239-51.

Dawkins, Richard. 2020. 'Quran's prophecy of COVID-19', Richard Dawkins Foundation, 8.9.2020, <https://richarddawkins.net/2020/09/qurans-prophecy-ofcovid-19/> (accessed 15.4.2021).

Daymon, Chelsea, and Mieli Criezis. 2020. 'Pandemic narratives: pro-Islamic state media and the coronavirus', CTC Sentinel 13(6): 26-32.

Dickinson, David L. 2020. 'Deliberation enhances the confirmation bias: an examination of politics and religion, IZA Discussion Papers No. 13241 (Bonn: Institute of Labor Economics (IZA)).

Dols, M.V. 2012. 'Djudham', in Encyclopaedia of Islam, Second Edition, eds. P. Bearman, Th. Bianquis, C. E. Bosworth, E. van Donzel and W. P. Heinrichs, (Leiden: Brill Online), doi: <http://dx.doi. org/10.1163/1573-3912_islam_SIM_8513>.

Eickelman, Dale F., and James P. Piscatori. 2004. Muslim Politics (Princeton University Press).

Fahmi, Georges. 2020. " "Pray in your homes": religion and the state in North Africa in times of COVID-19', IAI COMMENTARIES 20(53): 1-7, <https://www.iai.it/en/ pubblicazioni/pray-your-homes-religionand-state-north-africa-times-covid-19>.

Festinger, Leon. 1976. A Theory of Cognitive Dissonance (Stanford University Press).

Fibiger, Thomas Brandt, and Martin Riexinger. 2021. 'Islam og coronakrisen', Religion $i$ Danmark 10(1): 149-59.

Francesca, Ersilia. 2012. 'Dietary law', in Encyclopaedia of Islam, Three, eds. Kate Fleet, Gudrun Krämer, Denis Matringe, John Nawas, and Everett Rowson (Leiden: Brill Online), doi: <http://dx.doi. org/10.1163/1573-3912_ei3_COM_26018>.

Galal, Ehab. 2021. 'Med bønnens kraft. Et islamisk och kristent arabisk perspektiv på COVID-19', Tidskrift for Islamforskning 14(2): 113-39, doi: <https://doi. org/10.7146/tifo.v15i2.125961>.

Gambrell, Jon. 2020. 'Iran leader refuses us help, citing virus conspiracy theory', AP News, 26.3.2020, <https://apnews.com/art icle/2cffa 4c49cbfo8 5562 a $_{11} 1$ cd $_{3} 6 \mathrm{a}_{4}$ e $4378>$ (accessed 13.4.2021).

Gelman, Susan A. 2003. The Essential Child: Origins of Essentialism in Everyday Thought (New York: Oxford University Press).

-_—. 2013. 'Artifacts and essentialism', Review of Philosophy and Psychology 4(3): 449-63, doi: <https://doi.org/10.1007/ s13164-013-0142-7>.

Gleave, Robert. 2012. 'Makasid al-Shari'a', in Encyclopaedia of Islam, Second Edition, eds. P. Bearman, Emeri J. van Donzel, W. P. Heinrichs, Th. Bianquis, and C. E. Bosworth (Brill Online: Leiden), doi: <http://dx.doi. org/10.1163/1573-3912_islam_SIM_8809>.

Gori, Allessandro. 2021. 'Home prayer, unattended funerals and social responsibility: Muslims in Italy and the coronavirus outbreak (March-May 2020)', Tidskrift for Islamforskning 14(2): 63-80, doi: <https:// doi.org/10.7146/tifo.v15i2.125915>.

Guthrie, Stewart E. 1993. Faces in the Clouds: A New Theory of Religion (New York: Oxford University Press).

Hafer, Carolyn L., and Laurent Begue. 2005. 'Experimental research on just-world theory: problems, developments, and future challenges', Psychological Bulletin 131(1): 12867, doi: <10.1037/0033-2909.131.1.128>.

Hahn, Ulrike, and Adam J. L. Harris. 2014. 'What does it mean to be biased: 
motivated reasoning and rationality', Psychology of Learning and Motivation 61: 41-102, doi: <https://doi.org/10.1016/ B978-0-12-800283-4.00002-2>.

Harper, Mary. 2020. 'Coronavirus: fighting Al-Shabab propaganda in Somalia', BBC News, 2.4.2020, <https://www.bbc.com/ news/world-africa-52103799> (accessed 13.4.2021).

Haslam, Nick, Elise Holland, and Minoru Karasawa. 2013. 'Essentialism and entitativity across cultures', in Culture and Group Processes, eds. Masaki Yuki and Marilynn B. Brewer (Oxford University Press), 17-37.

Heinrichs, W. P. 2012. 'Kawa id Fikhiyya', in Encyclopaedia of Islam, 2nd edn, eds. P. Bearman, Th. Bianquis, C. E. Bosworth, E. van Donzel, and W. P. Heinrichs (Leiden: Brill Online), doi: <http://dx.doi. org/10.1163/1573-3912_islam_SIM_8763>.

Hopkins, Nick, and Stephen David Reicher. 2017. 'Social identity and health at mass gatherings', European Journal of Social Psychology 47(7): 867-77, doi: <https://doi. org/10.1002/ejsp.2288>.

Hult Khazaie, Daniella, and Sammyh S. Khan. 2020. 'Shared social identification in mass gatherings lowers health risk perceptions via lowered disgust', British Journal of Social Psychology 59(4): 839-56, doi: <https://doi. org/10.1111/bjso.12362>.

Islamic Affairs \& Charitable Activities Department. 2020. 'Al-Haddad: Muslims who die by corona virus are martyrs', Government of Dubai, 1.4.2020, <https://www.iacad.gov.ae/ en/Pages/NewsDetails.aspx?NewsID=707> (accessed 20.4.2021).

Islamic Relief. 2020. Guidance on Safe Religious Practice for Muslim Communities During the Coronavirus Pandemic (Birmingham: Islamic Relief Worldwide).

Joscelyn, Thomas. 2020. Twitter post, 1.4.2020, $<$ https://twitter.com/thomasjoscelyn/status/1245311851325423616> (accessed 13.9.2021).

Karic, Enes. 2001. 'Intoxicants', in Encyclopaedia of the Quran, ed. Jane Dammen McAuliffe (Leiden: Brill Online), doi: $<$ http://dx.doi.org/10.1163/1875-3922_q3_ EQSIM_00226>.

Katz, Marion Holmes. 2002. Body of Text: The Emergence of the Sunni Law of Ritual Purity
(Albany: State University of New York Press).

Keith, E. Stanovich, F. West Richard, and E. Toplak Maggie. 2013. 'Myside bias, rational thinking, and intelligence', Current Directions in Psychological Science: A Journal of the American Psychological Society 22(4): 259-64, doi: <https://doi. org/10.1177/0963721413480174>.

Kelly, Daniel R. 2011. Yuck! The Nature and Moral Significance of Disgust (Cambridge: MIT Press).

Khalid, Fazlun. 2019. Signs on the Earth: Islam, Modernity and the Climate Crisis (Marksfield: Kube Publishing Ltd).

Khan, Nazir, and Mufti Muntasir Zaman. 2020. 'The prophetic promises for martyrs and Medina: is COVID-19 a plague?', Yaqeen Institute for Islamic Research, 15.4.2020, $<$ https://yaqeeninstitute.org/nazir-khan/ the-prophetic-promises-for-martyrs-andmedina-is-covid-19-a-plague> (accessed 14.4.2021).

Khenenou, T., S. Laabed, and O. Laabed. 2020. 'Did the Quran mention COVID-19 pandemic? Medical and sanitary prophylaxis of this disease', Journal of Medical Biomedical and Applied Sciences 8(4): 375-7, doi: $<10.15520 /$ jmbas.v8i4.222 $>$.

Kohlberg, E. 2012. 'Shahid', in Encyclopaedia of Islam, Second Edition, eds. P. Bearman, Th. Bianquis, C. E. Bosworth, E. van Donzel and W. P. Heinrichs (Leiden: Brill Online), doi: <http://dx.doi.org/10.1163/15733912_islam_COM_1025>.

Lawson, E. Thomas, and Robert N. McCauley. 1990. Rethinking Religion: Connecting Cognition and Culture (Cambridge University Press).

Lewis, Bernard. 1988. The Political Language of Islam (University of Chicago Press).

Lim, Amanda. 2020. "Permissible and forgivable": Malaysia clarifies that alcohol-based hand sanitisers can be used by Muslims', Cosmetics design-asia.com, 24.3.2020, $<$ https://www.cosmeticsdesign-asia.com/ Article/2020/03/24/Malaysia-clarifies-thatalcohol-based-hand-sanitisers-can-beused-by-Muslims> (accessed 19.4.2021).

Madjid, Muh Naim. 2021. 'A lesson from corona virus disease 2019: exploring the science in the Book of Signs', in 4th 
International Conference on Sustainable Innovation 2020: Social, Humanity, and Education (ICoSIHESS 2020) (Amsterdam: Atlantis Press), 305-12, doi: <https://doi. org/10.2991/assehr.k.210120.139>.

Majra, Dasha, Jayme Benson, Jennifer Pitts, and Justin Stebbing. 2021. 'Sars-Cov-2 (COVID19) superspreader events', The Journal of Infection 82(1): 36-40, doi: <10.1016/j. jinf.2020.11.021>.

Medin, Douglas L., and Andrew Ortony. 1989. 'Psychological essentialism', in Similarity and Analogical Reasoning, eds. Stella Vosniadou and Andrew Ortony (Cambridge University Press), 179-95.

MEMRI. 2020. 'Al-Qaeda central: COVID19 is divine punishment for sins of mankind; Muslims must repent, West must embrace Islam, MEMRI, 1.4.2020, <https:// www.memri.org/reports/al-qaeda-centralcovid-19-divine-punishment-sins-mankind-muslims-must-repent-west-must > (accessed 14.4.2021).

Mercier, Hugo. 2017. 'Confirmation biasmyside bias', in Cognitive Illusions: Intriguing Phenomena in Thinking, Judgment and Memory, ed. Rüdiger F. Pohl (Routledge: London), 99-114.

Michalak, Laurence, and Karen Trocki. 2006. 'Alcohol and Islam: an overview', Contemporary Drug Problems 33(4): 523-62, doi: $<$ https://doi.org/10.1177/00914509060330 0401>.

Mufti of Federal Territory. 2020. 'Al-Kafi \# 1652: the usage of hand sanitizer and prayer', Mufti of Federal Territory, Malaysia, 11.3.2020, $<$ https://www.muftiwp.gov.my/en/artikel/ al-kafi-li-al-fatawi/4307-al-kafi-1652-penggunaan-hand-sanitizer-ketika-melakukansolat> (accessed 20.4.2021).

Musa, H. H., T. H. Musa, and I. H. Musa. 2020. 'COVID-19 outbreak controls: lesson learned from Islam', Ethics, Medicine, and Public Health 15(100561), doi: <https://doi. org/10.1016/j.jemep.2020.100561>.

Mustafa, Yassar. 2014. 'Islam and the four principles of medical ethics', Journal of Medical Ethics 40(7): 479-83, doi: <10.1136/ medethics-2012-101309>.

Nakissa, Aria. 2020a. 'Cognitive science of religion and the study of Islam: rethinking Islamic theology, law, education, and mysticism using the works of Al-Ghazali, Method \& Theory in the Study of Religion 32(3): 205-32, doi: <https://doi. org/10.1163/15700682-12341474>.

- - - 2020b. 'The cognitive science of religion and Islamic theology: an analysis based on the works of Al-Ghazali', Journal of the American Academy of Religion 88(4): 10871120, doi: <https://doi.org/10.1093/jaarel/ lfaa059>.

Nemeroff, Carol, and Paul Rozin. 1994. 'The contagion concept in adult thinking in the United States: transmission of germs and of interpersonal influence, Ethos 22(2): 158-86, doi: <https://doi.org/10.1525/ eth.1994.22.2.02a00020>.

- - . 2018. 'Back in touch with contagion: some essential issues', Journal of the Association for Consumer Research 3(4): 612-24, doi: <https://doi.org/10.1086/699971>.

Nichols, Ryan. 2014. 'Re-evaluating the effects of the 1755 Lisbon earthquake on eighteenthcentury minds: how cognitive science of religion improves intellectual history with hypothesis testing methods', Journal of the American Academy of Religion 82(4): 9701009, doi: <https://doi.org/10.1093/jaarel/ lfuo33>.

Office of the Mufti. 2020. 'Part 1: Religious position on COVID-19 vaccine (English)', Maijlis Ugama Islam Singapura, 13.12.2020, $<$ https://www.muis.gov.sg/officeofthemufti/ Irsyad/Part-11-Religious-position-onCOVID-19-vaccine-English> (accessed 5.3.2021)

Padela, Aasim I., Steven W. Furber, Mohammad A. Kholwadia, and Ebrahim Moosa. 2014. 'Dire necessity and transformation: entry-points for modern science in Islamic bioethical assessment of porcine products in vaccines', Bioethics 28(2): 59-66, doi: $<$ https://doi.org/10.1111/bioe.12016>.

Perho, Irmeli. 1995. The Prophet's Medicine: A Creation of the Muslim Traditionalist Scholars (Helsinki: Finnish Oriental Society).

Premack, David, and Guy Woodruff. 1978. 'Does the chimpanzee have a theory of mind, Behavioral and Brain sciences 1(4): 515-26, doi: <https://doi.org/10.1017/ s0140525x00076512>.

The President of Pakistan. 2020. Twitter post, 25.3.2020, <https:// 
twitter.com/Pres OfPakistan/status/1242774326962720768> (accessed 13.9.2021).

Rahmani, Hussein. 2020. 'Coronavirus: Dear Muslims, there is nothing called "Halal hand sanitizer", Hindustan Times, 18.3.2020, <https://www.hindustantimes.com/indianews/coronavirus-dear-muslims-thereis-nothing-called-halal-hand-sanitizer/ story-oPVyd62E52Pyf4gawXS9JM.html> (accessed 19.4.2021).

Riexinger, Martin. 2021. 'Islamic responses to the COVID-19 pandemic in India and Pakistan', Tidskrift for Islamforskning,14(2): 81-112, doi: <https://doi.org/10.7146/tifo. v15i2.125960>.

Riggio, Heidi R., Joshua Uhalt, Brigitte K. Matthies, Theresa Harvey, Nya Lowden, and Victoria Umana. 2018. 'Explaining death by tornado: religiosity and the godserving bias', Archive for the Psychology of Religion 40(1): 32-59, doi: <https://doi. org/10.1163/15736121-12341349>.

Rozin, Paul, and Carol Nemeroff. 1990. 'The laws of sympathetic magic', in Cultural Psychology: Essays on Comparative Human Development, eds. James W. Stigler, Richard A. Schweder, and Gilbert Herdt (Cambridge University Press), 205-32.

Rozin, Paul, and Carol Nemeroff, Marcia Wane, and Amy Sherrod. 1989. 'Operation of the sympathetic magical law of contagion in interpersonal attitudes among Americans', Bulletin of the Psychonomic Society 27(4): 367-70, doi: <https://doi.org/10.3758/ BFo3334630>.

Schaller, Mark, and Justin H. Park. 2011. 'The behavioral immune system (and why it matters)', Current Directions in Psychological Science 20(2): 99-103, doi: <https:/doi. org/10.1177/o963721411402596>.

Slone, D. Jason. 2004. Theological Incorrectness: Why Religious People Believe What They Shouldn't (Oxford University Press).

-——. 2005. 'Why religions develop freewill problems', in Mind and Religion: Psychological and Cognitive Foundations of Religiosity, eds. Harvey Whitehouse and Robert N McCauley (Walnut Creek: AltaMira Press), 187-206.

Sodian, Beate, and Susanne Kristen. 2010. 'Theory of mind', in Towards a Theory of
Thinking, eds. Britt Glatzeder, Vinod Goel and Albrecht von Müller (Berlin: Springer), 189-201.

Sofouglu, Murat. 2020. 'Could Islam's emphasis on hygiene make a difference in a pandemic?', TRT World, 16.4.2020, <https:// www.trtworld.com/magazine/could-islams-emphasis-on-hygiene-make-a-difference-in-a-pandemic-35469> (accessed 20.4.2021).

Sorgenfrei, Simon. 2021. " $P e r h a p s$ we see it in negative terms, but, ultimately it is positive", Tidskrift for Islamforskning 14(2): 40-62, doi: <https://doi.org/10.7146/tifo. v15i2.125959>.

Spilka, Bernard, and Greg Schmidt. 1983. 'General attribution theory for the psychology of religion: the influence of event-character on attributions to god', Journal for the Scientific Study of Religion 22(4): 326-39, doi: $<$ https://doi.org/10.2307/1385771>.

Stearns, Justin. 2007. 'Contagion in theology and law: ethical considerations in the writings of two 14th century scholars of Nașrid Granada, Islamic Law and Society 14(1): 109-29, doi: <https://doi.org/10.1163/1568 $51907780323852>$.

-_-. 2010. 'Contagion', in Encyclopaedia of Islam, Three, eds. Kate Fleet, Gudrun Krämer, Denis Matringe, John Nawas, and Everett Rowson (Leiden: Brill Online), doi: <http://dx.doi. org/10.1163/1573-3912_ei3_COM_23480>.

Stenberg, Leif. 1996. The Islamization of Science: Four Muslim Positions Developing an Islamic Modernity (Stockholm: Almqvist \& Wiksell International).

Sunnah.com, <https://sunnah.com/muslim $>$.

Svensson, Jonas. 2015. Människans Muhammed (Stockholm: Molin \& Sorgenfrei).

- - . 2017. 'Hurting the Qur'an: suggestions concerning the psychological infrastructure of desecration', Temenos 53(2): 243-64, doi: $<$ https://doi.org/10.33356/temenos.60297>.

- - . 2020. 'Ritualizing Muslim iconic texts', in The Oxford Handbook of Ritual and Worship in the Hebrew Bible, ed. S. E. Balentine (New York: Oxford University Press), 273-88.

- - . 2021. 'The contagious Muhammad: addressing prophetic relics in Islam from the perspective of the cognitive science of 
religion', Journal for the Cognitive Science of Religion 5(2): 187-204, doi: <10.1558/ jcsr.40987>.

Tamburini, Francesco. 2021. 'The COVID19 outbreak in North Africa: a legal analysis', Journal of Asian and African Studies, doi: <https://doi. org/10.1177/0021909620983586>.

al-Tamimi, Aymenn. 2020. 'Coronavirus and official Islamic state output: an analysis', GNET, 15.4.2020, <https:/gnet-research. $\mathrm{org} / 2020 / 04 / 15 /$ coronavirus-and-official-islamic-state-output-an-analysis/> (accessed 2.3.2021).

Tidskrift for Islamforskning 15(2): Mediated Religious and Political Perspectives on COVID19: Minority and Majority Views, <https:// tifoislam.dk/issue/view/9159/1402>.

UAE Council for Fatwa. 2020. 'UAE Council for Fatwa, Fatwa No. 11, 2020, pertaining to the rulings of performing congregational rites in light of the spread of COVID-19 (coronavirus disease), UAE Council for Fatwa, 3.3.2020, <http://binbayyah.net/english/ wp-content/uploads/2020/03/Fatwa-11COVID-19-final.pdf> (accessed 20.4.2021).

Umar, Mustafa, Hassan Elwan, and Osman Umarji. 2020. 'A punishment or a mercy? What we can learn from the coronavirus', Yaqeen Institute for Islamic Research, 14.4.2020, <https://yaqeeninstitute.org/ mustafa-umar/a-punishment-or-a-mercywhat-we-can-learn-from-the-coronavirus> (accessed 23.3.2021).

UNICRI. 2020. Stop the Virus of Disinformation (Torino: United Nations Interregional Crime and Justice Research Institute).

Wensinck, A. J. 2012b. 'Nadjis', in Encyclopaedia of Islam, Second Edition, eds. P. Bearman, Th. Bianquis, C. E. Bosworth, E. van Donzel and W. P. Heinrichs (Brill Online: Leiden). <http://dx.doi. org/10.1163/1573-3912_islam_SIM_5727>.

Wensinck, A. J., and J. Sadan. 2012. 'Khamr. 1. Juridical aspects', in Encyclopaedia of Islam, 2nd edn, eds. P. Bearman, Th. Bianquis, C. E. Bosworth, E. van Donzel, and W. P. Heinrichs (Leiden: Brill Online), doi: <http://dx.doi.org/10.1163/1573-3912_ islam_COM_0490>.

Whitehouse, Harvey. 2004. Modes of Religiosity: A Cognitive Theory of Religious Transmission (Walnut Creek: AltaMira Press).
WHO. 2020. Safe Ramadan Practices in the Context of the COVID-19 (World Health Organization).

Wielandt, Rotraud. 2001. 'Exegesis of the Qur'an: early modern and contemporary', in Encyclopaedia of the Qur'an, ed. Jane Dammen McAuliffe (Leiden: Brill Online), doi: <http://dx.doi.org/10.1163/18753922_Q3_EQCOM_00059>.

Xiong, Jianhui, Nazila Isgandarova, and Amy Elizabeth Panton. 2020. 'COVID-19 demands theological reflection: Buddhist, Muslim, and Christian perspectives on the present pandemic', International Journal of Practical Theology 24(1): 5-28, doi: <https:// doi.org/10.1515/ijpt-2020-0039>.

Zafrulla Khan, Muhammad. 1988. Islam and Human Rights (Tilford: Islam International). Zumla, Alimuddin, Esam I. Azhar, Saleh Alqahtani, Shuja Shafi, and Ziad A. Memish. 2020. 'COVID-19 and the scaleddown 2020 hajj pilgrimage: decisive, logical and prudent decision making by Saudi authorities overcomes pre-hajj public health concerns', International Journal of Infectious Diseases 99: 34-6, doi: <https://doi. org/10.1016/j.ijid.2020.08.006>. 